Article

\title{
Measured UV Exposures of Ironman, Sprint and Olympic-Distance Triathlon Competitors
}

\author{
Nathan J. Downs 1,2,*(D), Taryn Axelsen ${ }^{2}$, Alfio V. Parisi ${ }^{1,2} \mathbb{D}$, Peter W. Schouten ${ }^{2}$ and \\ Ben R. Dexter ${ }^{2}$ \\ 1 Centre for Applied Climate Sciences, University of Southern Queensland, Toowoomba 4350, Australia; \\ Parisi@usq.edu.au \\ 2 Faculty of Health, Engineering and Sciences, University of Southern Queensland, Toowoomba 4350, \\ Australia; Taryn.Axelsen@usq.edu.au (T.A.); peterschoutenau@gmail.com (P.W.S.); \\ Ben.Dexter@usq.edu.au (B.R.D.) \\ * Correspondence: nathan.downs@usq.edu.au
}

Received: 11 March 2020; Accepted: 24 April 2020; Published: 27 April 2020

\begin{abstract}
Triathletes present an extreme case of modelled behaviour in outdoor sport that favours enhanced exposure to solar ultraviolet radiation. This research presents personal solar ultraviolet exposures, measured using all-weather polysulphone film dosimeters, to triathletes during the distinct swimming, cycling and running stages of competitive Sprint, Olympic and Ironman events conducted within Australia and New Zealand. Measurements of exposure are made for each triathlon stage using film dosimeters fixed at a single site to the headwear of competing triathletes. Exposures are expressed relative to the local ambient and as absolute calibrated erythemally effective values across a total of eight triathlon courses (two Ironman, one half Ironman, one Olympic-distance, and four Sprint events). Competitor exposure results during training are also presented. Exposures range from between 0.2 to $6.8 \mathrm{SED} / \mathrm{h}$ (SED: standard erythema dose) depending upon the time of year, the local time of each event and cloud conditions. Cycle stage exposures can exceed 20 SED and represent the highest exposure fraction of any triathlon (average $=32 \%$ ). The next highest stage exposure occurred during the swim (average $=28 \%$ ), followed by the run (average $=26 \%$ ). During an Ironman, personal competitor exposures exceed $30 \mathrm{SED}$, making triathlon a sporting discipline with potentially the highest personal ultraviolet exposure risk.
\end{abstract}

Keywords: Ultraviolet; sport; triathlon; skin cancer; erythema; ironman

\section{Introduction}

Triathlon is an endurance sport contested over three distinct event stages, beginning with a swimming stage generally held in open water, transitioning to a bicycle road race and concluding with an endurance run. Triathlon events vary by total course length and are typically divided among Sprint, Olympic, half Ironman and Ironman events. Sprint events are one of the shortest forms of triathlon, with variations to this (e.g., super sprint), which may be contested over courses of varying lengths. A typical Sprint-distance triathlon requires triathletes to complete an open water swim stage of $750 \mathrm{~m}$ (this may vary depending on the location and set up of the course), a $20 \mathrm{~km}$ cycle race and a run stage of approximately $5 \mathrm{~km}$. Many locations and events offer a variation to the Sprint distance, with distances varying substantially between some locations and events. Olympic-distance events are contested over a $1.5 \mathrm{~km}$ swim, a $40 \mathrm{~km}$ cycle and a $10 \mathrm{~km}$ run. The endurance form of triathlon, known as an Ironman event, requires both male and female competitors to complete a $3.9 \mathrm{~km}$ swim, a $180 \mathrm{~km}$ bicycle road race and a $42.2 \mathrm{~km}$ marathon-distance run, with the half Ironman being half of these distances. Due to their extended duration, Ironman events typically take an entire day to complete. 
Wearable polymer film, biological spore and electronic dosimeters have been applied successfully to measure solar UV exposures incident on amateur and professional sportspeople across a range of disciplines and environments [1-3]. Unlike instrumentation such as radiometers that may be fixed and mounted to a specific site, personal dosimeters offer a lightweight, cost-effective and convenient measurement tool able to record an exposure over an extended interval of time that can be attached to a location on the body without interrupting the physical mobility of the study subject. Table 1 presents a range of studies completed over the past twenty years that have used personal dosimeters to measure solar ultraviolet (UV) exposure on participants engaged in outdoor sports and associated training activities. Sports such as skiing, golfing and cycling have been investigated extensively. However, there is currently limited data available on UV exposures measured for triathletes. It is likely that the necessity of the triathlete to transition between different event stages causes difficulty in measuring accurate personal exposures. This particular difficulty may be of greatest significance as the triathlete transitions from the swim to the cycle stage of an event as any dosimeters that need to be used must be water proof, and be easily exchanged by the competitor during the transition without the loss of time.

To date the only exposure study that has investigated the sport of triathlon was conducted by Moehrle [4]. Moehrle [4] reported the average erythemally effective solar UV exposure received exclusively during the combined bicycle and run stages for the Hawaii Ironman (world championships) of three competitive triathletes. Averaging an erythemally effective event exposure of 20.8 SED $\left(2080 \mathrm{Jm}^{-2}\right)$, these exposures, which were measured only during the cycle and run stage of the Ironman, represent the highest documented personal biologically effective sun exposure recorded in a single day for a competitive sport. This is likely to be a concern for elite and age-group athletes competing in day-long Ironman events. However, given the Ironman distance represents only one category of a sport increasing in popularity worldwide, this research seeks to examine the potential influence of the different categories of triathlon during each of the swim, cycle and run stages of an event, the effect of event timing, the effect of event location and the possible influence of training on the elective UV exposure risks triathletes face when competing. 
Table 1. A summary of recent studies demonstrating the variation in personal exposure measured using dosimeters across a range of outdoor sports. (SED: standard erythema dose).

\begin{tabular}{|c|c|c|c|}
\hline Activity/Sport Type & Author & Solar UV Exposure & Important Factors \\
\hline Ironman Triathlon & Moehrle [4] & $\begin{array}{l}\text { 20.8 SED (range of 17.3 SED to } 24.3 \text { SED) over the event } \\
\text { duration (cycle and run only) }\end{array}$ & Event schedule; Ambient UV \\
\hline Mountaineering & Moehrle et al. [5] & 6.6 SED daily (range of 0.6 to 24.2 SED) & Altitude; Albedo \\
\hline Cycling & Serrano et al. [7] & $\begin{array}{c}32.24 \pm 4.14 \text { SED in summer and } 11.30 \pm 5.36 \text { in winter } \\
\text { over two days }\end{array}$ & Season \\
\hline Cycling & Moehrle [8] & 16.2 SED daily in summer & Ambient UV \\
\hline Skiing & Rigel et al. [9] & 1 SED to 15.2 SED daily & Altitude; Albedo \\
\hline Hiking & Serrano et al. [11] & 8.1 SED daily in summer & Altitude; Ambient UV; Timing \\
\hline Tennis & Serrano et al. [11] & 7.5 SED daily in summer & Ambient UV; Timing \\
\hline Tennis & Serrano et al. [10] & $10.65 \pm 1.57$ SED over two days of training in summer & Exposure time; Timing \\
\hline Skiing & Serrano et al. [12] & 2.1 SED daily (range of 0.71 to 4.9 SED) & Albedo; Ambient UV \\
\hline Golf & Thieden et al. [13] & 0.7 SED to 3.7 SED daily & Individual behavior \\
\hline Golf & Downs et al. [14] & $\begin{array}{l}\text { 3.2 SED vertex exposures in summer to } 0.2 \mathrm{SED} \\
\text { (forearm) in winter per round }\end{array}$ & Season; Timing \\
\hline Running & Serrano et al. [10] & $7.62 \pm 4.28$ SED over five training days & Exposure time; Timing \\
\hline Golf & Gurrea Ysasi et al. [15] & $\begin{array}{c}\text { 2.07 SED in head position and 1.62 SED in wrist position } \\
\text { during winter per round }\end{array}$ & Season; Exposure time \\
\hline Running & Serrano et al. [11] & 2 SED daily in summer & Ambient UV; Timing \\
\hline Running & Nurse et al. [16] & $\begin{array}{l}0.093 \text { SED approximately } 4 \mathrm{~h} \text { early morning (range of } \\
0.062 \text { to } 0.136 \text { SED) }\end{array}$ & Exposure time; Timing \\
\hline
\end{tabular}




\section{Materials and Methods}

Measurements of personal solar UV exposure for the sport of triathlon were made over three individual training sessions and eight competitive triathlon events contested within Australia and New Zealand between November 2017 and December 2018. Events were contested over Sprint, Olympic, half Ironman and Ironman distances. Triathlon sites included three suburbs of Brisbane $\left(27.5^{\circ} \mathrm{S}\right.$ $\left.153.0^{\circ} \mathrm{E}\right)$ : Bribie Island (27.0 $\left.\mathrm{S}, 153.1^{\circ} \mathrm{E}\right)$, Raby Bay $\left(27.5^{\circ} \mathrm{S}, 153.3^{\circ} \mathrm{E}\right)$, and Springfield $\left(27.7^{\circ} \mathrm{S}, 152.9^{\circ} \mathrm{E}\right)$; four event sites located within Queensland, New South Wales and Western Australia: Mooloolaba $\left(26.7^{\circ} \mathrm{S} 153.1^{\circ} \mathrm{E}\right)$, Robina $\left(28.1^{\circ} \mathrm{S} 153.4^{\circ} \mathrm{E}\right)$, Byron Bay $\left(28.6^{\circ} \mathrm{S}, 153.6^{\circ} \mathrm{E}\right)$, and Busselton $\left(33.7^{\circ} \mathrm{S}\right.$, $\left.115.3^{\circ} \mathrm{E}\right)$; and one site located in New Zealand: Taupo $\left(37.7^{\circ} \mathrm{E} 176.1^{\circ} \mathrm{E}\right)$. The location, event type, local starting time of each triathlon stage and event date are listed in Table 2. Minimum and maximum temperature recorded in the 24-hour period of each event $[17,18]$ and MODIS Terra cloud fraction expressed in octa (eighths) [19] are also listed in Table 2. Event locations are shown in Figure 1.

Table 2. Scheduled participant triathlon events listed by event category in the period 2017 to 2018.

\begin{tabular}{|c|c|c|c|c|c|c|c|c|}
\hline Event & Location & Date & Type & Stages & Distances & Local Start & $\begin{array}{l}\text { Temperature } \\
(\mathrm{min} / \mathrm{max})\end{array}$ & $\begin{array}{l}\text { Cloud } \\
\text { Fraction }\end{array}$ \\
\hline $\begin{array}{l}\text { Bribie Island } \\
\text { (Qld-Aus) }\end{array}$ & $\begin{array}{c}27.0^{\circ} \mathrm{S} \\
153.1^{\circ} \mathrm{E}\end{array}$ & $\begin{array}{c}26 \\
\text { November } \\
2017\end{array}$ & $\begin{array}{l}\text { Long } \\
\text { Sprint }\end{array}$ & $\begin{array}{l}\text { Swim } \\
\text { Cycle } \\
\text { Run }\end{array}$ & $\begin{array}{c}1 \mathrm{~km} \\
29 \mathrm{~km} \\
7.5 \mathrm{~km}\end{array}$ & $\begin{array}{l}\text { 7:30 am } \\
\text { 7:50 am } \\
8: 46 \mathrm{am}\end{array}$ & $18.3 / 29.0^{\circ} \mathrm{C}$ & 5 octa \\
\hline $\begin{array}{l}\text { Raby Bay } \\
\text { (Qld-Aus) }\end{array}$ & $\begin{array}{c}27.5^{\circ} \mathrm{S} \\
153.3^{\circ} \mathrm{E}\end{array}$ & $\begin{array}{c}11 \\
\text { December } \\
2017\end{array}$ & $\begin{array}{l}\text { Long } \\
\text { Sprint }\end{array}$ & $\begin{array}{l}\text { Swim } \\
\text { Cycle } \\
\text { Run }\end{array}$ & $\begin{array}{l}0.9 \mathrm{~km} \\
25 \mathrm{~km} \\
5.6 \mathrm{~km}\end{array}$ & $\begin{array}{l}\text { 7:55 am } \\
\text { 8:17 am } \\
\text { 9:08 am }\end{array}$ & $18.9 / 27.5^{\circ} \mathrm{C}$ & 5 octa \\
\hline $\begin{array}{c}\text { Robina } \\
\text { (Qld-Aus) }\end{array}$ & $\begin{array}{c}28.1^{\circ} \mathrm{S} \\
153.4^{\circ} \mathrm{E}\end{array}$ & $\begin{array}{c}14 \\
\text { January } \\
2018\end{array}$ & Olympic & $\begin{array}{l}\text { Swim } \\
\text { Cycle } \\
\text { Run }\end{array}$ & $\begin{array}{l}1.5 \mathrm{~km} \\
40 \mathrm{~km} \\
10 \mathrm{~km}\end{array}$ & $\begin{array}{l}\text { 7:00 am } \\
7: 33 \mathrm{am} \\
8: 45 \mathrm{am}\end{array}$ & $34.4 / 24.7^{\circ} \mathrm{C}$ & 2 octa \\
\hline $\begin{array}{l}\text { Taupo } \\
\text { (NZ) }\end{array}$ & $\begin{array}{c}38.7^{\circ} \mathrm{E} \\
176.1^{\circ} \mathrm{E}\end{array}$ & $\begin{array}{l}3 \text { March } \\
2018\end{array}$ & Ironman & $\begin{array}{l}\text { Swim } \\
\text { Cycle } \\
\text { Run }\end{array}$ & $\begin{array}{l}3.8 \mathrm{~km} \\
180 \mathrm{~km} \\
42.2 \mathrm{~km}\end{array}$ & $\begin{array}{l}\text { 6:15 am } \\
7: 30 \mathrm{am} \\
1: 18 \mathrm{pm}\end{array}$ & $15 / 22{ }^{\circ} \mathrm{C}$ & 8 octa \\
\hline $\begin{array}{c}\text { Bribie Island } \\
\text { (Qld-Aus) }\end{array}$ & $\begin{array}{c}27.0^{\circ} \mathrm{S} \\
153.1^{\circ} \mathrm{E}\end{array}$ & $\begin{array}{l}25 \text { March } \\
2018\end{array}$ & Sprint & $\begin{array}{l}\text { Swim } \\
\text { Cycle } \\
\text { Run }\end{array}$ & $\begin{array}{c}0.75 \mathrm{~km} \\
20 \mathrm{~km} \\
5 \mathrm{~km}\end{array}$ & $\begin{array}{l}7: 30 \mathrm{am} \\
7: 44 \mathrm{am} \\
8: 24 \mathrm{am}\end{array}$ & $17.6 / 26.1^{\circ} \mathrm{C}$ & 8 octa \\
\hline $\begin{array}{l}\text { Byron Bay } \\
\text { (NSW-Aus) }\end{array}$ & $\begin{array}{c}28.6^{\circ} \mathrm{S} \\
153.6^{\circ} \mathrm{E}\end{array}$ & $\begin{array}{c}12 \text { May } \\
2018\end{array}$ & Sprint & $\begin{array}{l}\text { Swim } \\
\text { Cycle } \\
\text { Run }\end{array}$ & $\begin{array}{c}0.75 \mathrm{~km} \\
20 \mathrm{~km} \\
5 \mathrm{~km}\end{array}$ & $\begin{array}{c}12: 20 \mathrm{pm} \\
12: 40 \mathrm{pm} \\
1: 24 \mathrm{pm}\end{array}$ & $11.4 / 20.1^{\circ} \mathrm{C}$ & 0 octa \\
\hline $\begin{array}{l}\text { Mooloolaba } \\
\text { (Qld-Aus) }\end{array}$ & $\begin{array}{c}26.7^{\circ} \mathrm{S} \\
153.1^{\circ} \mathrm{E}\end{array}$ & $\begin{array}{c}26 \\
\text { August } \\
2018\end{array}$ & Half-Ironman & $\begin{array}{l}\text { Swim } \\
\text { Cycle } \\
\text { Run }\end{array}$ & $\begin{array}{l}1.9 \mathrm{~km} \\
90 \mathrm{~km} \\
21 \mathrm{~km}\end{array}$ & $\begin{array}{l}6: 17 \mathrm{am} \\
6: 54 \mathrm{am} \\
9: 35 \mathrm{am}\end{array}$ & $15.2 / 20.8^{\circ} \mathrm{C}$ & 2 octa \\
\hline $\begin{array}{l}\text { Busselton } \\
\text { (WA-Aus) }\end{array}$ & $\begin{array}{c}33.7^{\circ} \mathrm{S} \\
115.3^{\circ} \mathrm{E}\end{array}$ & $\begin{array}{c}2 \\
\text { December } \\
2018\end{array}$ & Ironman & $\begin{array}{l}\text { Swim } \\
\text { Cycle } \\
\text { Run }\end{array}$ & $\begin{array}{c}3.8 \mathrm{~km} \\
180 \mathrm{~km} \\
* 21.3 \mathrm{~km}\end{array}$ & $\begin{array}{l}\text { 6:46 am } \\
7: 57 \mathrm{am} \\
1: 23 \mathrm{pm}\end{array}$ & $12.4 / 26.8^{\circ} \mathrm{C}$ & 7 octa \\
\hline
\end{tabular}

* Injury during the Busselton Ironman prevented the participant from completing a $42.2 \mathrm{~km}$ run.

Event training was also monitored for a single study participant. Periods of personal training for triathlon events including environment conditions on the date of training [17-19] are provided in Table 3. Training for the study participant took place in Springfield (Queensland). The total time spent outdoors while training for each triathlon stage is listed in Table 3 and was determined by the triathlete. Unlike the events listed in Table 2, the time spent outside while training is not dependent on a specified course length. Event training took place between 29 October and 13 November 2017. 
Table 3. Scheduled triathlete training periods in 2017.

\begin{tabular}{|c|c|c|c|c|c|c|c|c|}
\hline Event & Location & Date & Type & Stages & $\begin{array}{l}\text { Exposure } \\
\text { Time }\end{array}$ & Local Start & $\begin{array}{c}\text { Temperature } \\
(\min / \max )\end{array}$ & $\begin{array}{l}\text { Cloud } \\
\text { Fraction }\end{array}$ \\
\hline $\begin{array}{l}\text { Springfield } \\
\text { (Qld-Aus) }\end{array}$ & $\begin{array}{c}27.7^{\circ} \mathrm{S} \\
152.9^{\circ} \mathrm{E}\end{array}$ & $\begin{array}{l}29 \text { October } \\
2017\end{array}$ & Training & $\begin{array}{l}\text { Cycle } \\
\text { Run } \\
\text { Swim }\end{array}$ & $\begin{array}{l}3 \mathrm{~h} 42 \mathrm{~min} \\
39 \mathrm{~min} \\
52 \mathrm{~m}\end{array}$ & $\begin{array}{l}\text { 6:16 am } \\
\text { 10:19 am } \\
2: 11 \mathrm{pm}\end{array}$ & $20.7 / 31.5^{\circ} \mathrm{C}$ & 2 octa \\
\hline $\begin{array}{l}\text { Springfield } \\
\text { (Qld-Aus) }\end{array}$ & $\begin{array}{c}27.7^{\circ} \mathrm{S} \\
152.9^{\circ} \mathrm{E}\end{array}$ & $\begin{array}{l}12 \text { November } \\
2017\end{array}$ & Training & $\begin{array}{l}\text { Cycle } \\
\text { Run }\end{array}$ & $\begin{array}{l}5 \mathrm{~h} 18 \mathrm{~min} \\
37 \mathrm{~min}\end{array}$ & $\begin{array}{c}5: 52 \mathrm{am} \\
11: 36 \mathrm{am}\end{array}$ & $11.9 / 25.7^{\circ} \mathrm{C}$ & 8 octa \\
\hline $\begin{array}{l}\text { Springfield } \\
\text { (Qld-Aus) }\end{array}$ & $\begin{array}{c}27.7^{\circ} \mathrm{S} \\
152.9^{\circ} \mathrm{E}\end{array}$ & $\begin{array}{l}13 \text { November } \\
2017\end{array}$ & Training & Swim & $1 \mathrm{~h} 37 \mathrm{~min}$ & 8:59 am & $13.4 / 26.0^{\circ} \mathrm{C}$ & 7 octa \\
\hline
\end{tabular}

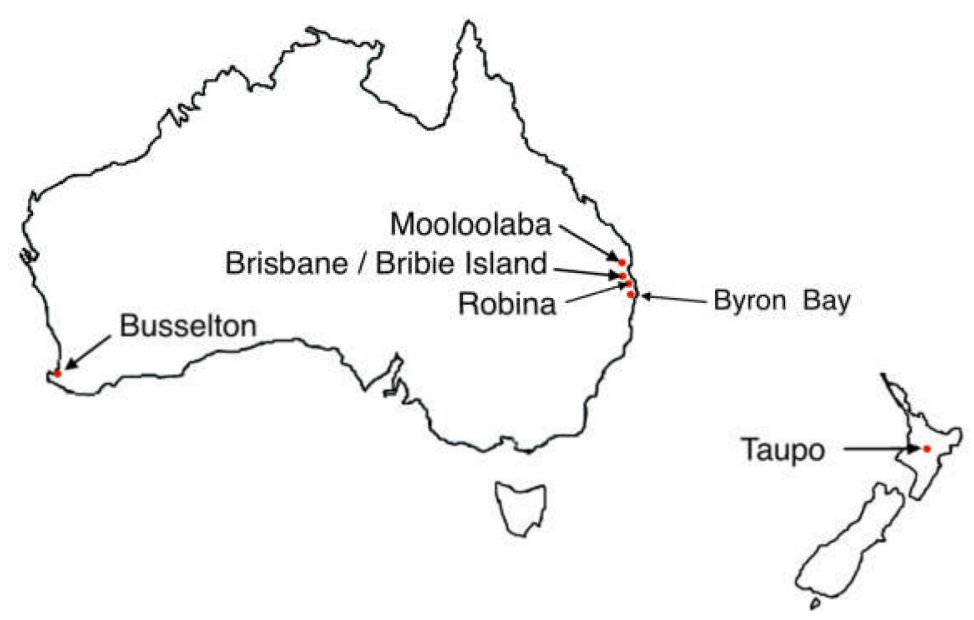

Figure 1. Triathlon event locations. Springfield and Raby Bay are suburbs of the greater Brisbane area. North is at top and scale is approximately $35 \times 50^{\circ}$.

Polysulphone (PS) dosimeters manufactured from thin film strips with an approximate thickness of 40 microns were distributed as badges to all study participants. PS film dosimeters are useable in all weather conditions [20] and were chosen for this application in triathlon to also enable measurement of exposure during the swimming stage of each scheduled event. These badge-type dosimeters (Figure 2), when mounted to a flexible polymer frame $(15 \times 10 \mathrm{~mm})$ are lightweight and have a clear circular aperture of $6 \mathrm{~mm}$ covered by PS, which undergoes a change in absorbance at $330 \mathrm{~nm}$ as a result of exposure to UV radiation.

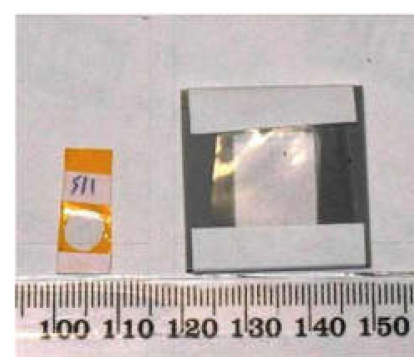

(a)

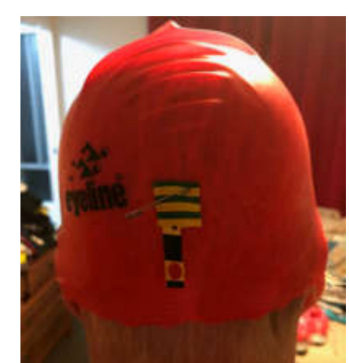

(b)

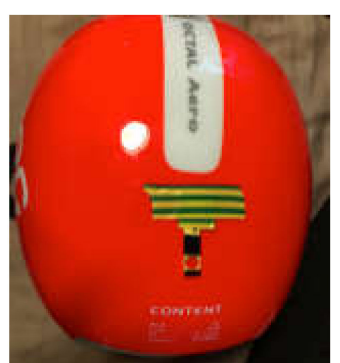

(c)

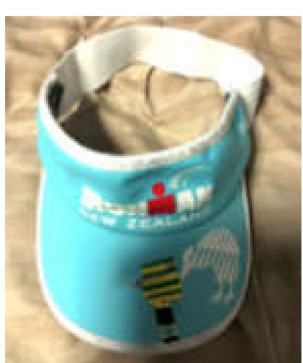

(d)

Figure 2. Polysulphone film dosimeters used in this study were adhered to small flexible frames notably smaller than badges used in similar studies (a), that were pinned to the swimming cap (b), bicycle helmet (c) and cap (d) of each participant.

The change in absorbance, $\Delta A_{330}$, was measured as the difference in PS film absorbance at $330 \mathrm{~nm}$ pre- and post-exposure at four sites and averaged across each PS dosimeter. The average $\Delta A_{330}$ of a set of eight dosimeters was calibrated to a field radiometer maintained as part of the Australian 
Radiation and Nuclear Safety Authority (ARPANSA) national UV radiation monitoring network [21]. The radiometer, located in Brisbane, measures the cumulative erythemally effective [22] solar UV in $\mathrm{J} \mathrm{m}^{-2}$. To calibrate the PS badges, the $\Delta A_{330}$ of the calibration dosimeters was plotted against the cumulative UV exposure measured during a midmorning calibration interval in the Brisbane area. A single A4 sheet of PS film was used to cast all dosimeters used in the study. For the eight dosimeters used in the calibration the average PS film absorbance measured pre-exposure $(n=32)$ was $0.136 \pm 9 \%$ ( \pm 1 s.d). Here, PS film post-exposure measurements were made several days after the calibration to minimize post-exposure differences caused by the dark reaction of PS film. This reaction results in a change in optical absorbance of around $4 \% 24 \mathrm{~h}$ following an exposure which stabilizes thereafter [23]. The calibration was performed on 18 February 2018 (late summer in the southern hemisphere).

Figure 3 shows the calibration curve of the PS film used for the personal UV badges distributed in this study. The practical limit of dosimeters calibrated to this curve for field exposure during a triathlon event enabled personal measurements of exposure up to approximately 15 SED, where 1 SED is the equivalent of $100 \mathrm{Jm}^{-2}$ erythemally effective UV [22]. A cubic function was fitted to the Brisbane calibration dosimeters. The fitted calibration function is shown in Figure 3 for erythemally effective exposures exceeding a $\Delta A_{330}$ of 0.35 . In practice, this limit was not exceeded for personal exposures recorded in and around the Brisbane area during the local triathlon series or participants' training periods. The calibration curve was applied to dosimeter exposures measured at each triathlon event between 2017 and 2019.

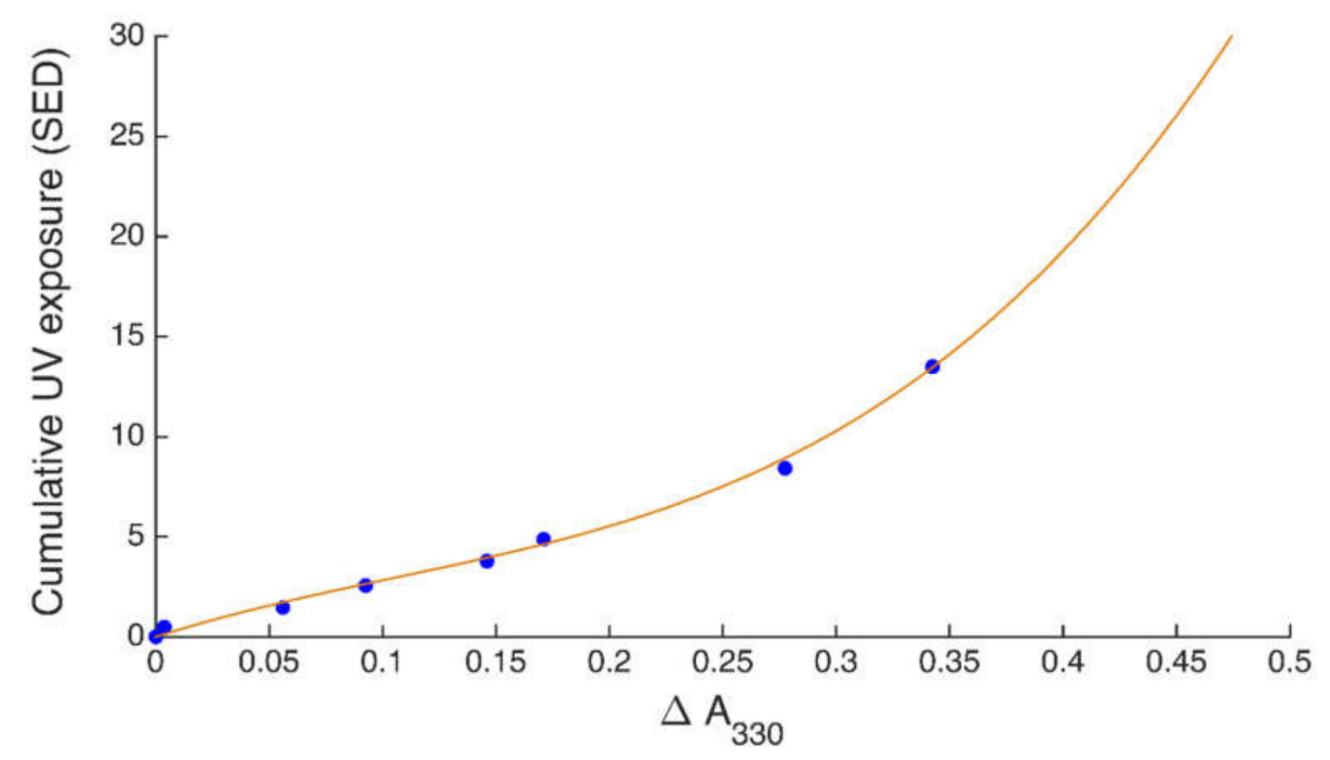

Figure 3. Field calibration of poylsulphone film dosimeters to the Brisbane Australian Radiation and Nuclear Safety Authority radiometer, 18 February 2018 (ARPANSA 2018).

For triathlon events and training sessions conducted in and around Brisbane, the calibration of the PS badges enables direct measurement of personal erythemal UV exposure. For triathlon events held outside the southern Queensland area, the calibration to the ARPANSA Brisbane radiometer provides a less reliable indication of personal exposure. This is because the available solar radiation used to calibrate PS film changes depending upon the solar elevation, the season and atmospheric conditions, resulting in a measurable change in $\Delta A_{330}$ which in turn influences the shape of the respective calibration curve [24,25]. To account for this, PS dosimeters are generally calibrated relative to the local environment before being deployed for the measurement of personal UV exposure. At the sites of several triathlon events studied in this research, including Taupo (New Zealand), Busselton (Western Australia) and Byron Bay (New South Wales) local field radiometers were not available for local calibration of triathlete dosimeters. Absolute calibrations to the 18 February calibration for events 
held outside summer months and away from Brisbane are therefore only approximations and are highlighted in Table 4 . Therefore, UV exposures measured during the swim, cycle and running stages of each event were also expressed relative to the available ambient. Here, ambient UV exposure was recorded by separate field dosimeters left in place on an undisturbed horizontal plane at the event site for the duration of each triathlon. This technique was applied to derive the relative stage exposure (RSE) with respect to the total available ambient.

Competitor RSE was determined at each event for PS dosimeters attached to the headwear of study participants. Here, $\Delta A_{330}$ was expressed relative to the available ambient exposure, $E$ recorded by field dosimeters placed upon a horizontal plane where the exposure of PS film for each dosimeter varies according to the general cubic function [26]:

$$
E=K\left(9 \Delta A_{330}^{3}+\Delta A_{330}^{2}+\Delta A_{330}\right)
$$

In Equation (1), $K$ is a constant that is dependent upon calibration to a local field radiometer. In the absence of a local radiometer, personal dosimeter exposures were expressed here relative to $\Delta A_{\text {hor }}$, where $\Delta A_{\text {hor }}$ represents the measured change in PS absorbance at $330 \mathrm{~nm}$ for field dosimeters placed upon a horizontal plane for the duration of each triathlon event. The constant $K$ is eliminated when deriving the RSE (Equation (2)), which in turn can be expressed as a percentage of the local ambient erythemally effective UV,

$$
R S E=\frac{9 \Delta A_{330}^{3}+\Delta A_{330}^{2}+\Delta A_{330}}{9 \Delta A_{\text {hor }}^{3}+\Delta A_{\text {hor }}^{2}+\Delta A_{\text {hor }}} \times 100
$$

Study participants included active triathletes engaged in any form of the sport (Sprint, Olympic, half Ironman or Ironman). A single participant was recruited for each event. Thus, event exposures represent the exposure received by an individual participant on the day of each triathlon. Event start and stage times were also recorded by study participants. Permission to recruit participants was obtained according to national research standards involving human subjects and approved by the University of Southern Queensland human ethics committee (USQ approval no. H18REA033F1).

Prior to being given a study pack which included a paper sun exposure duration diary and six PS dosimeters, participants were instructed in the correct handling and storage of PS film. This included instruction on the use of lightproof envelopes for storing badges before and after exposure to solar UV radiation and handling instructions to prevent fingerprinting the exposed clear aperture of each PS badge. In this research, triathletes attached a single PS dosimeter to the back of a swimming cap, the back of a bicycle helmet and top of a hat or cap that would be used for each triathlon event stage (Figure 2). These sites were chosen to enable triathletes to attach dosimeters quickly during event stage intervals, but also to approximate exposures received by body surfaces orientated horizontally during competition (expressing the likely worst-case personal exposure). Headwear exposure measurements were also taken using the same method during event training. During a triathlon, the swimming cap, helmet and hat were each stored in lightproof bags when not in use and left in the transition area. Each triathlete began exposing personal dosimeters by opening storage bags and donning the respective headwear with the attached dosimeter at the beginning of a triathlon stage. At the end of each event stage, as the triathlete transitioned from one activity to another, the swimming cap, helmet and hat were again stored away in their lightproof bags. Following exposure, all triathlete dosimeters were returned to the University of Southern Queensland for processing via return mail. All mail return times exceeded one calendar week. Post-exposure absorbance measurements of PS film were made as soon as dosimeters were returned.

At the beginning of each triathlon, three dosimeters attached to a small card were placed and weighted upon the ground in an open position at the location of the event. These three dosimeters remained in position for the entire duration of all swimming, cycling and running stages of the triathlon 
and so recorded the total ambient solar radiation used to derive the respective stage exposure ratios (RSE-Equation (2)).

\section{Results}

Personal UV exposures measured during each triathlon and during periods of training prior to the nine scheduled triathlon events are listed in Table 4. Ambient UV index (UVI) range recorded during training and event stage times by ARPANSA radiometers are also listed for days where data is available for radiometers located in Brisbane (Springfield, Bribie Island, Raby Bay, Robina) and Perth (Busselton). Triathlete exposures listed in SED are based on the Brisbane summer dosimeter calibration of 18 February 2018. ARPANSA exposures in SED are estimated from the ARPANSA UV radiometer dose website and rounded here to the nearest half-hourly interval [27]. Triathlon events in Table 4 are listed in chronological order.

Table 4. Participant training and triathlon UV exposure, including relative stage exposure (RSE) for triathlons measured with respect to event ambient dosimeters. $d / d=$ damaged dosimeter. ARPANSA UVI = ambient UVI during event stages [21] including integrated exposure in standard erythema dose (SED) [27]. (UV: Ultraviolet, UVI: UV index)

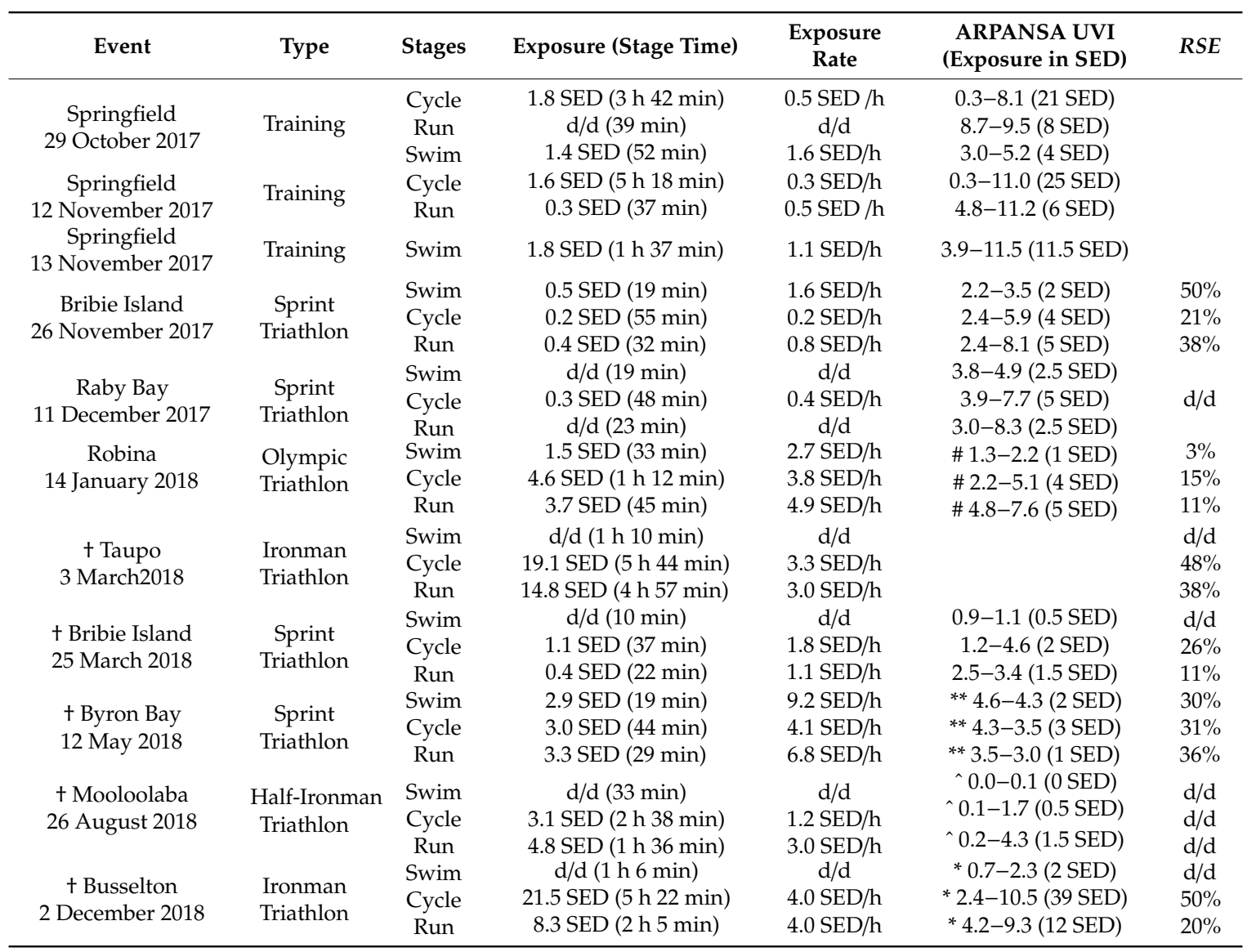

+ Calibrated dosimeters are approximations being held outside summer months and away from Brisbane; \# The Brisbane ARPANSA radiometer is located approximately $70 \mathrm{~km}$ from Robina; ${ }^{\wedge}$ The Brisbane ARPANSA Radiometer is located approximately $75 \mathrm{~km}$ from Mooloolaba; ${ }^{* *}$ The Brisbane ARPANSA Radiometer is located approximately $145 \mathrm{~km}$ from Byron Bay; * The Perth ARPANSA radiometer is located approximately $195 \mathrm{~km}$ from Busselton.

Of all personal solar UV exposures measured during competitive triathlon events, the Ironman events held at Taupo (New Zealand) and Busselton (Western Australia) resulted in the highest exposures. Exposures measured during the bicycle stage of the Taupo and Busselton Ironman events were 19.1 and 21.5 SED respectively. The next highest exposures of all nine monitored triathlon events occurred during the running stages of Taupo (14.8 SED) and Busselton (8.3 SED). The ambient $\Delta A_{\text {hor }}$ measured 
during each Ironman event reached an average of 0.53 (12 h $0 \mathrm{~min}$ ) and 0.59 ( $8 \mathrm{~h} 41 \mathrm{~min}$ ) between Taupo and Busselton respectively. These ambient dosimeter exposures were the highest recorded of all nine triathlon events. As clearly shown in Table 4, Ironman triathletes were exposed to the available ambient solar radiation for the longest duration of all three triathlon categories.

At Taupo, the event of 3 March 2018 resulted in competitor times that varied from $8 \mathrm{~h} 0 \mathrm{~min}$ to $16 \mathrm{~h}$ $58 \mathrm{~min}$ with our study competitor achieving a total race time of $11 \mathrm{~h}$ and $51 \mathrm{~min}$ [28]. This compares with the shortest triathlon competitor time recorded by our study participants between 2017 to 2018 of $69 \mathrm{~min}$, achieved during the Bribie Island Sprint event of 25 March 2018. The much shorter duration of the Sprint event greatly reduced the competitor's UV exposure to 1.5 SED, which was measured over the Bribie Island Sprint event during the cycle and run stage. Measured exposures made during the half Ironman and Olympic-distance events were the next highest of all nine triathlons compared to the remaining Sprint triathlon distance events. By event category, the highest exposures were therefore measured according to total course distance. Course distance has a direct influence on competitor event time such that Ironman events resulted in elevated total exposures compared with Olympic-distance events, followed by Sprint distance triathlons. For the shorter distance variants of triathlon, which attract a large number of amateur competitors, event timing and course planning are therefore important qualifiers for determining personal competitor exposure risk.

Table 4 lists the ambient UV index recorded by ARPANSA radiometers during triathlon events and triathlon training. A UVI reaching 3 is the equivalent to an erythemally effective irradiance of $75 \mathrm{~mW} \mathrm{~m}^{-2}$ and is considered within the low range of an open-ended categorisation that includes moderate (UVI 4-5), high (UVI 6-7), very high (8-10) and extreme (11+) categories. Of the seven triathlon events where local UVI could be estimated by ARPANSA radiometers, most (five) began during periods of low UVI. These included the Bribie Island Sprint triathlon of 26 November 2017, the Bribie Island Sprint triathlon of 25 March 2018, the Robina Olympic triathlon of 14 January 2018, the Mooloolaba half Ironman of 26 August 2018 and the Ironman event held at Busselton on 2 December 2018. Only the Raby Bay (11 December 2017) Sprint triathlon began during a period of moderate UVI. This triathlon commenced at 7:55 am. Compared with the other five triathlons, which took place in proximity to an ARPANSA radiometer and which all begin prior to 7:30 am local time, the Raby Bay event presented a high risk to triathletes because it occurred closer to the peak daily exposure period of local solar noon which occurs close to 12:00 pm in the sub-tropics. Exposure to solar UV was also likely to be high during the Raby Bay triathlon because it occurred during a time of year when the annual solar UV irradiance is greatest in the southern hemisphere, only 10 days before the summer solstice on 21 December.

Total personal exposure could not be measured across all event stages of the Raby Bay Sprint triathlon of 11 December 2017, nor did this triathlon experience a high exposure rate. A possible explanation for this is cloud cover. As observed by the change in ARPANSA UVI recorded during the Raby Bay event (Table 4), the UVI fluctuated from low (3.0) to very high (8.3) during the final triathlon run stage. Cloud cover during the Bribie Island Sprint triathlon of 26 November 2017 also shows evidence of a wide variation in ambient UVI, ranging from 2.4 to 8.1 during the final run stage of the event. Such variation, explicable only by the presence of cloud cover (Figure 4) is likely to be responsible for the generally low total exposure measured during this Sprint triathlon of 1.1 SED (swim, cycle and run). 


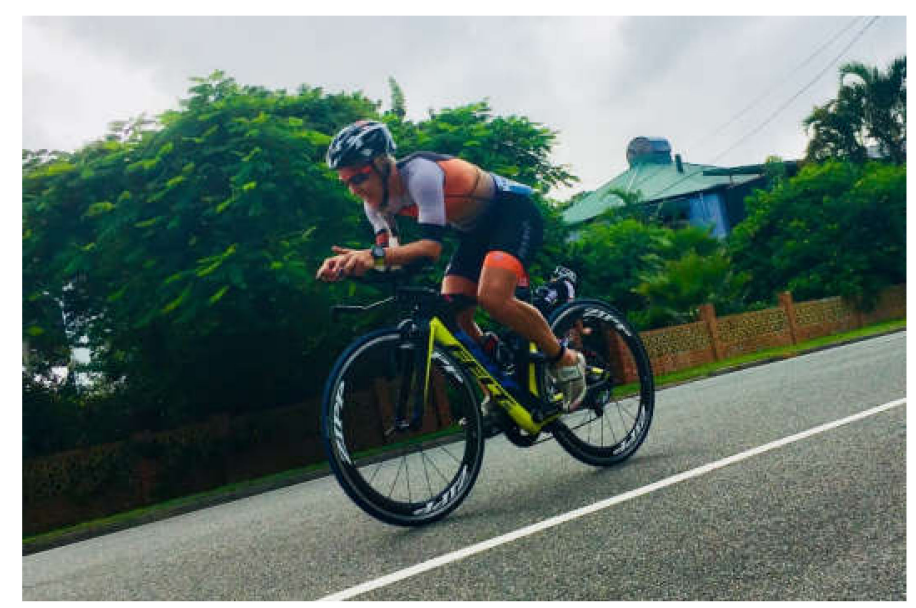

Figure 4. The $20 \mathrm{~km}$ bicycle stage of a long course sprint triathlon, Bribie Island, Queensland 25 March 2018. Cloudy conditions visible in the photograph on this day attenuate potentially very high exposures to the neck, arms and legs (see also Table 2).

The final stage of any triathlon that commences in the morning is the run stage, which generally occurs closest to the peak solar noon period (in the absence of cloud cover). As observed in the results presented in Table 4, the highest competitor exposure rate of $6.8 \mathrm{SED} / \mathrm{h}$ was received at a cap vertex site during the running stage of the Byron Bay Sprint triathlon of 12 May 2018. Unlike all other listed triathlon events which commenced in the morning, the Byron Bay event began in the early afternoon and close to the midday peak exposure period. Here, the timing of the event is likely to be a very significant factor. Apart from the likelihood that the Byron Bay Sprint triathlon occurred during a period of very high UVI, only the Ironman triathlons and personal training sessions conducted in Springfield were monitored during continuous periods of very high to extreme UVI. These elective exposures received during training present very high risk to triathletes preparing for competition because they were conducted in the early summer (Southern Hemisphere) and during periods at or near solar noon.

Training exposure rates were highest during swim training (Table 4). Here training exposures were monitored while training at a local outdoor pool rather than the open ocean. Of all triathlon stages, swimming requires athletes to expose themselves in an environment that provides no shade protection. Water and sand are more reflective than a ground surface covered by grass [29]. This may be a contributing factor to the elevated UV exposure observed during swim training and swim stages of competitive triathlons. However, the absence of shade in or near an ocean environment has been highlighted previously as the more likely explanation for elevated solar UV exposure than surface albedo reflections from water or sand surfaces [30]. Being exposed in an open environment may possibly explain the high UV exposure rates observed during swim training and the swim stages of triathlon events presented in Table 4. Being placed in a prone position while swimming is another factor that may explain high swimming UV exposure rates as the body, when swimming, experiences less overall range of movement, with the head placed consistently in an orientation level to the water surface.

\section{Discussion}

Whether a triathlon is a Sprint, an Olympic-distance or an Ironman event, being at the top end of any competitive field will reduce a competitor's total exposure risk. This is because total exposure time can significantly influence the effective personal dose a competitor receives when exposed to the available solar radiation in an outdoor environment. Of all of the main triathlon classes which begin in the morning, the cycle and running stages often coincide with peak ambient exposure times near solar noon. A total of eight scheduled triathlon events commenced during the morning before 8:00 
am in our event sample studied between 2017 and 2018. The RSE, which expresses the total stage exposure relative to the available ambient, was highest for the cycle stage, varying from between $15 \%$ and $50 \%$. This was followed by the running stage of a triathlon (11\% to 38\%). For Ironman events, which run over an entire day, the necessity to compete in a cycle and running stage makes exposure to potentially harmful solar UV unavoidable. As shown in the measured exposures presented in this research, the length of an Ironman is the principal reason for competitors at these events recording the highest exposures of all triathlon classes. This is because competitors of Ironman events are exposed for a longer time period but are also exposed during a time of day when the solar UV irradiance is at its peak.

In triathlon, the swimming stage starts first, followed by a transition to a bicycle race and finally a run to the finish. Starting early in the morning limits the potential biological damage competitors receive as a result of exposure to ambient solar radiation. This is likely to be of particular importance to triathlon as the swimming stage places athletes in an open unprotected environment and in a prone position for much of the stage (Figure 5). Unfortunately for this research, a high number of returned PS dosimeters used after a swimming stage had become brittle and had split following their return to the university for post-exposure processing. This may have been a consequence of the film becoming wet. In the future, this may be remedied by making dosimeter exposure measurements immediately following an event if practicable. Nevertheless, ratios of body site exposure $(E R)$ recorded in other studies and expressed relative to the available ambient demonstrate a high exposure potential to the arms of swimmers $(E R=0.74)$ [31], compared to competitive cyclists $(E R=0.71)$ [32] and runners $(E R=0.33)[16]$. A swimmer who is placed in a prone position during a triathlon would therefore expect to receive a high relative exposure. A comparison of the RSE between all event stages shows the cycle stage $R S E$ was often this highest (average $R S E=32 \%$ ), followed by the swim stage (average $R S E=28 \%$ ) and the run (average $R S E=26 \%$ ). Even though the swim stage takes the shortest amount of time to complete, this does not prevent it from having a total UV exposure comparable to the cycle and run stages. Sunscreen and protective clothing may prevent potentially damaging personal exposures during the swim.

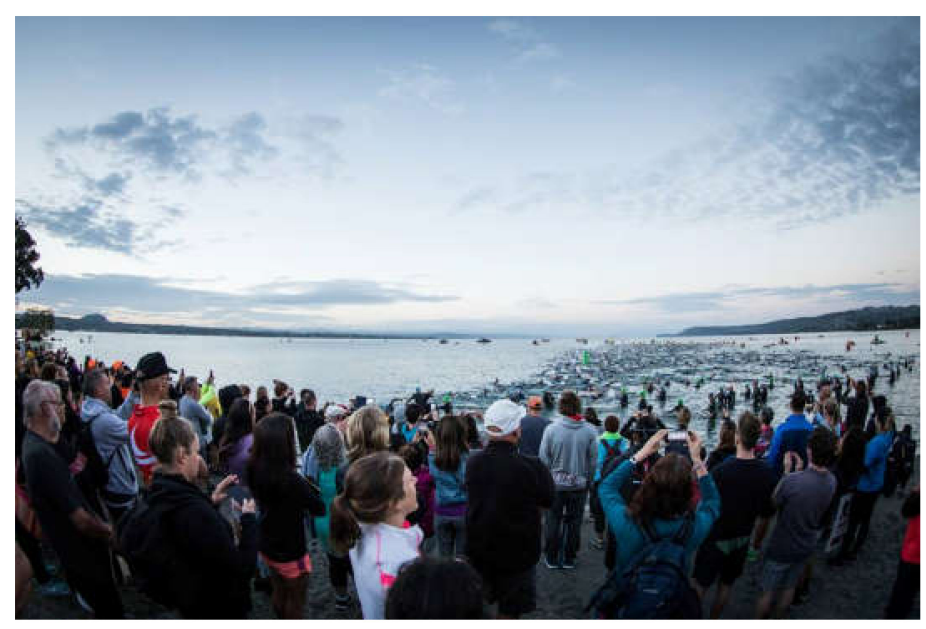

Figure 5. The swimming stage of an Ironman event $3.8 \mathrm{~km}$, Lake Taupo, New Zealand $\left(38.7^{\circ} \mathrm{S} 176.1^{\circ} \mathrm{E}\right)$ 3 March 2018. Open swimming environments present no shade for competitors who are placed in a prone position for the duration of the stage.

In triathlon, generally the only change of clothing that occurs during the entire event is the removal of a wetsuit (if allowed; only in cooler water temperatures) following the swim stage. If triathletes are required to wear full body length wetsuits the UV exposure risk during the swim stage can be largely mitigated, however their use may be prohibited depending upon the swim stage's length and water 
temperature. Wetsuits cannot be used in triathlon events when water temperatures exceed $24.6^{\circ} \mathrm{C}$ for swim courses greater than $1501 \mathrm{~m}$ in length [33].

Mandatory requirements implemented as part of the rules and regulations of a triathlon event offer an opportunity to reduce potentially harmful exposure to solar UV radiation. One such strategy could involve the application of sunscreen. While sunscreen is not always effective in water [34], and would likely have minimal effect if a triathlon commenced early in the morning before the UV reached a moderate level, it could be applied instead at the beginning of the road cycling race as the triathlete transitions from the early morning swim stage. Such a strategy would be most effective if the application of sun protection was made a mandatory requirement of the sport. At the present time, half Ironman and Ironman events offer sunscreen in both T1 (transition from the swim to cycle stage) and T2 (transition from the cycle to the run), however it is not a mandatory requirement and many competitors do not reapply sunscreen during the transitions to save time.

Exposures received when the sun is low in the sky during the early morning and late afternoon represent periods of minimal daily exposure risk. National cancer councils and advocacy groups recommend exposure avoidance, active use of shade, and personal sun-protection when the UVI reaches a moderate level [35]. Exposures received during periods of low UVI may not therefore require active sun-protection by triathlon competitors. One strategy that could be implemented to improve sun protection during periods of a triathlon when the greatest amount of solar UV radiation is present would involve active promotion of the use of physical sun protection during the cycle and run stage. Courses designed to make use of well shaded streets, parks and forests have the potential to limit the effective skyview and therefore provide greater opportunity to shade competitors (Figure 6). Here, a new metric, the RSE was introduced to measure the relative difference in exposure across each of the swim, cycle and run stages of a triathlon. Local shading experienced by a competitor as they move around a course will affect each triathlon event differently. Therefore, the RSE measured with respect to a static field dosimeter placed in an open environment measures the relative exposure of each triathlete only with respect to that location. Similarly, given the limited number of ARPANSA radiometers available, any given RSE exposure expressed with respect to a field dosimeter will not be exactly the same as the exposures provided by the radiometers. These radiometers do however give some idea of the influence of cloud cover and show that the UVI (and therefore exposure) can also fluctuate depending on the cloud conditions experienced during an event.

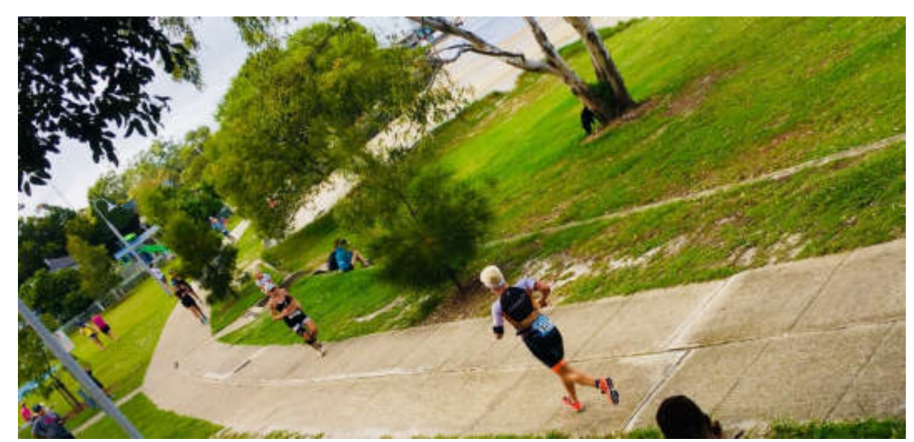

Figure 6. Running stage of an Ironman event $42.2 \mathrm{~km}$, Taupo New Zealand ( $\left.38.7^{\circ} \mathrm{S} 176.1^{\circ} \mathrm{E}\right) 3 \mathrm{March}$ 2018. This stage typically takes the longest amount of time to run in a triathlon but provides good opportunity for event organisers to make use of shaded locations.

Apart from course design, local variation in weather can make a significant difference to the personal UV exposure received. Although local variations in cloud cover can also significantly impact the available solar UV radiation (where optically dense rain-bearing clouds are most effective in reducing the available ambient UV), the type and level of protection from cloud cover is difficult to predict. More predictable is the annual variation in ambient solar UV due to the time of year. As triathlon is a sport that is conducted year round, event planners and competitors may seek to 
minimise exposure risk by avoiding exposure during summer. Exposure avoidance is especially important during events (or triathlon stages) scheduled during noon periods when the available UVI is highest. Such a strategy may be particularly important for Ironman event schedules as these events by necessity take an entire day to complete, and avoiding potentially harmful summertime peak noon-time exposures cannot be achieved effectively by stage design alone.

Triathlete exposures measured in this research for the Ironman swim, cycle and run stage range from 8.3 to 21.5 SED. These results compare closely with those measured by Moehle [4] which varied between 17.3 to 24.3 SED for the combined running and cycle stages of the Hawaii Ironman. Here, total exposure measured during the Australian and New Zealand Ironman events exceeded 29.8 SED and 33.9 SED for Busselton and Taupo respectively. Table 1 shows a selection of sports for which personal exposures have been measured. Of these, mountaineering [5] and snow skiing [6] also demonstrate a very high personal UV exposure risk (with snow skiing recording the highest personal exposure measured in a sport at 32.24 SED). However, if swimming exposure (and the greater unprotected skin surface area of the triathlete) were taken into account, it would seem likely that triathlon presents potentially the highest elective UV exposure risk of any sport.

\section{Conclusions}

This research has demonstrated that triathlon as a sporting discipline can present competitors with extreme UV exposure risk over each of the swim, cycle and running stages of an event. When considering the sport, it is important to measure the UV exposure experienced by a participant during each of the necessary event stages. Here, an all-weather PS dosimeter was employed to derive personal measurement of UV exposure. These measurements build upon and add to the measurements made previously by Moehle [4] showing that triathlon as a sport, contested over a rage of categories, can result in a wide range of personal exposures that can also potentially be mitigated by event planning and the implementation of strategies that target the personal protection of competitors placed in an outdoor environment.

Triathletes exposed to prolonged periods of sunlight, in warm climates and without a high level of sun-protective clothing are at risk of developing keratinocyte skin cancer and cutaneous melanoma, and also immune suppression, skin photoageing and ocular disorders such as cortical cataract and pterygium. The measurements provided in this research support a limited body of evidence to date showing the very high exposure potential of this particular sport. Measurements of personal exposure undertaken using a variety of dosimeter types will add to the growing number of personal exposure studies in all sports. Hopefully more such studies will consider triathlon in the future. While triathletes engage in what is essentially an endurance sport that encourages a vigorous level of exercise, this research has demonstrated the need to balance the health benefits of an active lifestyle, with the latent threat of prematurely induced skin and eye disease caused by UV exposure. This will require careful planning of event timing, an understanding of the local environment and greater consideration of the personal factors that influence solar UV dose by course designers, governing associations and the triathletes themselves.

Author Contributions: Conceptualization, N.J.D. and A.V.P.; Methodology, N.J.D. and A.V.P.; Software, N.J.D.; Validation, N.J.D., A.V.P. and P.W.S.; Formal Analysis, A.V.P. and N.J.D.; Investigation, T.A.; Resources, T.A. and N.J.D.; Data Curation, N.J.D.; Writing-Original Draft Preparation, N.J.D., T.A., P.W.S., A.V.P. and B.R.D.; Writing-Review \& Editing, N.J.D., A.V.P., T.A., P.W.S. and B.R.D.; Visualization, T.A. and N.J.D.; Supervision, N.J.D. and A.V.P.; Project Administration, N.J.D. and T.A.; Funding Acquisition, N.J.D. All authors have read and agreed to the published version of the manuscript.

Funding: This research received no external funding.

Acknowledgments: The authors would like to thank the volunteer triathletes who took part in this study for their support of this research.

Conflicts of Interest: The authors declare no conflict of interest. 


\section{References}

1. Moehrle, M. Outdoor sports and skin cancer. Clin. Dermatol. 2008, 26, 12-15. [CrossRef] [PubMed]

2. Schmalwieser, A.W.; Sianni, A.M. Review of nonoccupational personal solar UV exposure measurements. Photochem. Photobiol. 2018, 94, 900-915. [CrossRef] [PubMed]

3. Downs, N.J.; Parisi, A.V.; Schouten, P.W.; Igoe, D.P.; De Castro-Maqueda, G. The simulated ocular and whole-body distribution of natural sunlight to kiteboarders: A high risk case of UVR exposure for athletes utilizing water surfaces in sport. Photochem. Photobiol. 2020. [CrossRef] [PubMed]

4. Moehrle, M. Ultraviolet exposure in the ironman triathlon. Med. Sci. Sport Exerc. 2001, 33, 1385-1386. [CrossRef]

5. Moehrle, M.; Dennenmoser, B.; Garbe, C. Continuous long-term monitoring of UV radiation in professional mountain guides reveals extremely high exposure. Int. J. Cancer 2003, 103, 775-778. [CrossRef]

6. Casale, G.R.; Siani, A.M.; Diémoz, H.; Agnesod, G.; Parisi, A.V.; Colosimo, A. Extreme UV index and solar exposures at Plateau Rosà (3500 m a.s.l) in Valle d'Aosta region, Italy. Sci. Total Environ. 2015, 512, 622-630. [CrossRef]

7. Serrano, M.; Cañada, J.; Moreno, J. Erythemal ultraviolet exposure of cyclists in Valencia, Spain. Photochem. Photobiol. 2010, 86, 716-721. [CrossRef]

8. Moehrle, M.; Heinrich, L.; Schmid, A.; Garbe, C. Extreme UV exposure of professional cyclists. Dermatology 2000, 201, 44-45. [CrossRef]

9. Rigel, E.G.; Lebwohl, M.G.; Rigel, A.C.; Rigel, D.S. Ultraviolet radiation in alpine skiing: Magnitude of exposure and importance of regular protection. Arch. Dermatol. 2003, 139, 60-62. [CrossRef]

10. Serrano, M.A.; Cañada, J.; Moreno, J. Ultraviolet exposure for different outdoor sports in Valencia, Spain. Photodermatol. Photoimmunol. Photomed. 2011, 27,311-317. [CrossRef]

11. Serrano, M.A.; Cañada, J.; Moreno, J.; Gurrea, G. Personal UV exposure for different outdoor sports. Photochem. Photobiol. Sci. 2014, 13, 671-679. [CrossRef] [PubMed]

12. Serrano, M.A.; Cañada, J.; Moreno, J. Erythemal ultraviolet solar radiation doses received by young skiers. Photochem. Photobiol. Sci. 2013, 12, 1976-1983. [CrossRef] [PubMed]

13. Thieden, E.; Philipsen, P.; Heydenreich, J.; Wulf, H. UV radiation exposure related to age, sex, Ocupation, and sun behavior based on time-stamped personal dosimeter readings. Arch. Dermatol. 2004, 140, 197-203. [CrossRef] [PubMed]

14. Downs, N.; Schouten, P.; Parisi, A.V.; Turner, J. Measurements of the upper body ultraviolet exposure to golfers: Non-melanoma skin cancer risk, and the potential benefits of exposure to sunlight. Photodermatol. Photoimmunol. Photomed. 2009, 25, 317-324. [CrossRef]

15. Gurrea Ysasi, G.; Moreno, J.; Serrano, M.A. Ultraviolet erythematic radiation dose received by golfers in winter, in Valencia. Photochem. Photobiol. 2014, 90, 1170-1173. [CrossRef]

16. Nurse, V.; Wright, C.Y.; Allen, M.; McKenzie, R.L. Solar ultraviolet radiation exposure of South African marathon runners during competition marathon runs and training sessions: A feasibility study. Photochem. Photobiol. 2015, 91, 971-979. [CrossRef]

17. BoM (Bureau of Meteorology-Australia). Climate Data Online. Available online: http://bom.gov.au/climate/ data. (accessed on 9 April 2020).

18. T\&D (TimeandDate.com), Past Weather in Taupo, New Zealand-March 2018. Available online: https://www. timeanddate.com/weather/new-zealand/taupo/historic?month=3\&year=2018. (accessed on 9 April 2020).

19. NASA. GIOVANNI v4.33, MODIS Terra-Cloud Fraction from Cloud Mask: Mean of Daily Mean, MOD08 D3 v6.1. Available online: https://giovanni.gsfc.nasa.gov/giovanni/ (accessed on 9 April 2020).

20. Siani, A.M.; Casale, G.R.; Modesti, S.; Parisi, A.V.; Colosimo, A. Investigation on the capability of polysulphone for measuring biologically effective solar UV exposures. Photochem. Photobiol. Sci. 2014, 13, 521-530. [CrossRef]

21. ARPANSA (Australian Radiation and Nuclear Safety Authority). Ultraviolet Radiation Index. Available online: https://www.arpansa.gov.au/our-services/monitoring/ultraviolet-radiation-monitoring/ultravioletradiation-index (accessed on 26 February 2020).

22. CIE Standard. Erythema Reference Action Spectrum and Standard Erythema Dose, CIE S 007/E-1998; Commission Internationale de l'Eclairage: Vienna, Austria, 1998. 
23. Davis, A.; Deane, G.H.W.; Diffey, B.L. Possible dosimeter for ultraviolet radiation. Nature 1976, 261, $169-170$. [CrossRef] [PubMed]

24. Casale, G.R.; Borra, M.; Colosimo, A.; Colucci, M.; Militello, A.; Siani, A.M.; Sisto, R. Variability among polysulphone calibration curves. Phys. Med. Biol. 2006, 51, 4413-4427. [CrossRef]

25. Casale, G.R.; Siani, A.M.; Diémoz, H.; Kimlin, M.G.; Colosimo, A. Applicability of the polysulphone horizontal calibration to differently inclined dosimeters. Photochem. Photobiol. 2011, 88, 207-214. [CrossRef]

26. Diffey, B.L. Ultraviolet radiation dosimetry with polysulphone film. In Radiation Measurement in Photobiology; Diffey, B.L., Ed.; Academic Press: London, UK, 1989.

27. ARPANSA (Australian Radiation and Nuclear Safety Authority). Ultraviolet Radiation Dose. Available online: https://www.arpansa.gov.au/our-services/monitoring/ultraviolet-radiation-monitoring/ultravioletradiation-dose. (accessed on 15 April 2020).

28. Ironman New Zealand. Available online: https://www.sportsplits.com/races/14898 (accessed on 28 February 2020).

29. Chadyšiene, R.; Girgždys, A. Ultraviolet radiation albedo of natural surfaces. J. Environ. Eng. Landsc. 2008, $16,83-88$.

30. Diffey, B.L. Time and place modifiers of personal UV exposure. Int. J. Environ. Res. Public Health 2018, 15, 1112. [CrossRef] [PubMed]

31. Herlihy, E.; Gies, P.H.; Roy, C.R.; Jones, M. Personal dosimetry of solar UV radiation for different outdoor activities. Photochem. Photobiol. 1994, 60, 288-294. [CrossRef]

32. Kimlin, M.G.; Martinez, N.; Green, A.C.; Whiteman, D.C. Anatomical distribution of solar ultraviolet exposures among cyclists. J. Photochem. Photobiol. B 2006, 85, 23-27. [CrossRef] [PubMed]

33. ITU (International Triathlon Union). ITU Competition Rules. Available online: https://www.triathlon.org/ uploads/docs/itusport_competition-rules_2019.pdf (accessed on 4 March 2020).

34. Poh Agin, P. Water resistance and extended wear sunscreens. Dermatol. Clin. 2006, 24, 75-79. [CrossRef]

35. Cancer Council. UV Index. Available online: https://www.cancer.org.au/preventing-cancer/sun-protection/ uv-alert/ (accessed on 4 March 2020).

(C) 2020 by the authors. Licensee MDPI, Basel, Switzerland. This article is an open access article distributed under the terms and conditions of the Creative Commons Attribution (CC BY) license (http://creativecommons.org/licenses/by/4.0/). 